Original Research Paper

\title{
Study on the Relationship between International and Domestic Grain Prices in Developing Countries-An Application of Markov-Switching Autoregressive Model-
}

\author{
${ }^{1}$ Shuqin Yan, ${ }^{2}$ Kolawole Ogundari, ${ }^{1}$ Hiroshi Isoda and ${ }^{1}$ Shoichi Ito \\ ${ }^{1}$ Department of Agricultural and Resource Economics, Faculty of Agriculture, Kyushu University, Fukuoka, Japan \\ ${ }^{2}$ Department of Applied Economics and Statistics, University of Delaware, Newark, USA
}

Article history

Received: $15-12-2015$

Revised: 27-07-2016

Accepted: 30-07-2016

Corresponding Author:

Shuqin Yan

Department of Agricultural and Resource Economics, Faculty of Agriculture, Kyushu

University, Fukuoka, Japan

Email: ysq2003508@163.com

\begin{abstract}
This study aims at estimating the influence of international grain prices on the domestic grain prices in 24 developing countries using a nonlinear model, Markov-Switching Autoregressive model. The results indicate that international grain prices have a positive influence on domestic grain prices before and during/after the grain price-hikes, while the degree of influence may vary depending upon grains and countries. Overall, the influences of the international grain prices on domestic grain prices during/after the price-hikes are less than before in those countries where rice or maize are staple food such as for rice in Benin, Cameroon, Niger and Tunisia and for maize in Chad, Guatemala and Nicaragua; however, the influences are generally larger than before the price-hikes for those countries where wheat is staple food such as Armenia, Georgia, Mauritania and Pakistan. For the effects of domestic prices in previous periods, they had a positive influence on current domestic grain prices in most of the countries in this study.
\end{abstract}

Keywords: Grain Price-Hikes, Markov-Switching Autoregressive (MSAR) Model, Regimes, International/Domestic Prices

\section{Introduction}

From 2007 to mid-2008, the international grain prices showed a series of sharp fluctuation trend. In the mid2008 , the prices of rice, wheat and maize were more than two times the price level they were in 2006 (Fig. 1) and these sharp increases in food prices possibly led to grain price instability in a number of developing countries. In fact, the grain prices including rice, wheat and maize have again risen since 2010 after drops in 2009 and are still relatively high till date. Understanding the price transmission between the domestic and international grain prices in developing countries help policy makers understand consumer welfare behavior given the fact that international grain prices have sharply increased and decreased in 2008 (Fig. 1) and the argument that there is a surge in domestic grain prices during and after the grain-price crisis in developing countries. In view of this development, we assumed that the domestic prices may respond differently from the international prices before and during/after the grain price-hikes and it might have occurred that the domestic grain prices may have two different periods.
Kim (1994) proposed State-Space Models with Markov-Switching model. This model not only identifies the time-varying parameters and latent variable parameters but also depicts the changes in different states of the time series data and more complex dynamic evolution of the data. While the Markov-Switching model has great flexibility in modeling regime-dependent time series data, it can also be used to study the business cycle and financial markets because of the fact that an empirical application has been linked to economic and political events. Accordingly, Yarmohammad et al. (2012) compared Markov-Switching Autoregressive model (MSAR) and six different time series modeling approaches to capture the Iranian exchange rate series. The results indicated that MS-AR model could be considered a useful model with the best fit to evaluate the behaviors of Iran's exchange rate. Ailliot and Monbet (2012) used nonhomogeneous Markov-Switching Autoregressive (MSAR) models to describe wind time series. Several autoregressive models in this study are used to describe the time evolution of the wind speed and the switching between these different models is controlled by a hidden Markov chain which represents the weather types. 


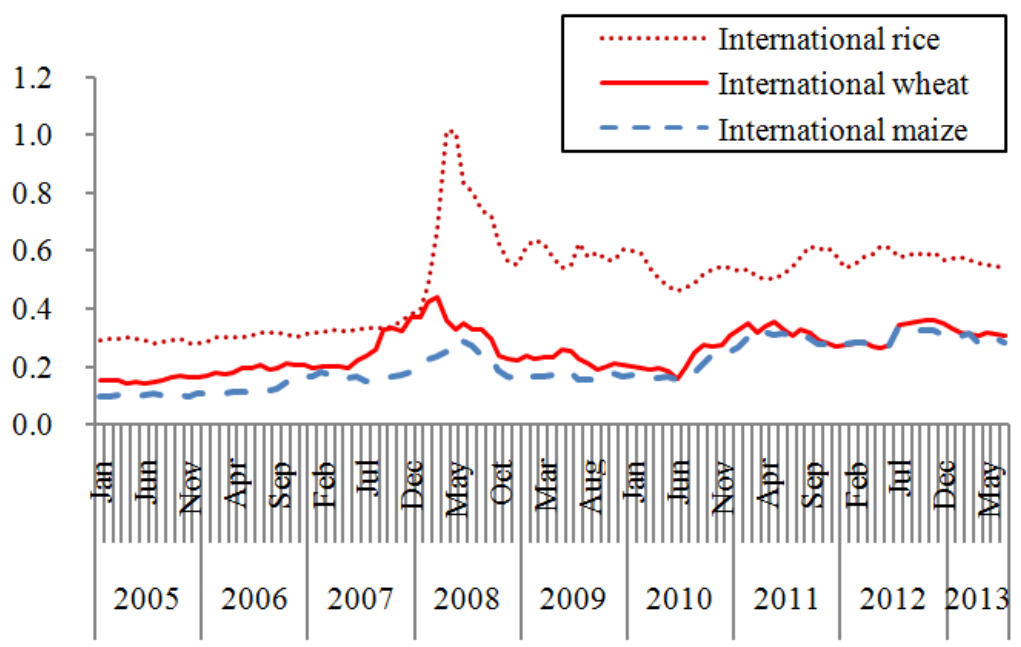

Fig. 1. Fluctuation of international grain prices, Data source: International Monetary Fund (IMF), International Financial Statistics (IFS), Rice: $5 \%$ broken milled white rice, Thailand; Wheat: No.1, Hard Red winter, ordinary protein, FOB Gulf of Mexico; Maize: U.S. No.2 Yellow, FOB Gulf of Mexico. US. Price Unit, US\$/metric ton. All the prices data are nominal prices

Furthermore, a literature search finds that a number of studies have employed Markov-Switching model in agricultural economics. For example, Brummer et al. (2009) used a Markov-Switching Vector Error-Correction Model (MS-VECM) to estimate multiple regime shifts in the relationship between wheat and wheat flour prices in Ukraine from June 2000 to November 2004. The analysis revealed four regimes whose timing coincided with political and economic events in Ukraine. Ihle et al. (2009) used MS-VECM model to analyze spatial maize price transmission processes between Tanzania and Kenya. The results of the MS-VECM also indicated that it could serve as a guide toward improving our understanding of the determinants of price transmission between the neighboring countries.

Meanwhile, a review of the literature shows that a large number of studies have been used to raise political influence on the link between domestic and international food prices, after the surge in the global food prices in particular. Prakash (2011) reviewed a considerable amount of studies focusing on price volatility in the developing countries. Arezki et al. (2011) studied the volatility of commodity prices on the basis of a large dataset of monthly prices observed in international trade data from the United States over the period 2002 to 2011. Huchet-Bourdon (2011) examined the question of whether commodity price volatility materially changed with the rapid run up in world prices during 2006 and 2009 followed by an equally sharp decline in many commodity prices afterwards. In these reports, analyzed were international price volatility for selected agricultural commodities over the past half-century and their relationship with crude oil, fertilizer and the eurodollar exchange rates. Pindyck (2004) examined the role of volatility in short-run commodity market dynamics and the determinants of volatility. His paper developed a structural model of inventories, spot and futures prices.

However, few reports employed a non-linear model to investigate price transmission between domestic and international food prices. A Markov-Switching model is a regime-switching model, which employs an economic variable in relation to unobservable shifts between regimes. Therefore, this study attempts to contribute further to the existing research by employing the Markov-Switching Autoregressive (MS-AR) model, a nonlinear model, to investigate the relationship between international grain prices and domestic prices in 24 developing countries following the work by Ihle et al. (2009), who used the Markov-Switching model in spatial maize price transmission processes between the neighboring countries.

\section{Data and Methodology}

Data

The data used in this study include retail grain price series for rice, wheat and maize from the international market and domestic markets covering 24 developing countries. Because the purpose of this study is to estimate how international grain prices influence domestic grain prices in developing countries, we collected as much grain prices data for developing countries as possible. We chose all the grain price data which were available on the website as described below. The prices are for Laos and Philippines (East Asia and Pacific); Armenia, Georgia and Kyrgyzstan (Europe and Central Asia); Brazil, Guatemala, Nicaragua, Panama, Peru and The Dominican Republic 
(Latin America and Caribbean); Tunisia (Middle East and North Africa); Nepal, Pakistan and Sri Lanka (South Asia); and Benin, Burundi, Cameroon, Cape Verde, Chad, Niger, Madagascar, Togo and Mauritania (Sub-Saharan Africa). These countries include all the types of developing countries and they cover lowincome ( $\leqq 1,035$ per person), lower middle income $(\$ 1,036 \sim \$ 4,085)$ to upper middle income $(\$ 4,086 \sim \$ 12,615)$ groups (WB, 2013).

The international data are monthly times series data covering from January 2005 to July 2013 obtained from the website of the International Financial Statistics (IFS) and World Economic Outlook Database published by (IMF, 2006-2014). The domestic grain prices are the GIEWS Food Price Data and Analysis Tool from the Food and Agriculture Organization (FAO) website (FAO, 2014a). All the prices data are nominal prices data and the unit is USD/ton.

\section{Methodology}

If economic data are non-stationary in nature, this could give rise to spurious regression results; therefore, we employed unit root tests such as Augmented Dickey-Fuller (ADF) test (Dickey and Fuller, 1979) and the Phillips-Perron (PP) test (Phillips and Perron, 1988) to check whether or not the price series were stationary on the original level or at the first/second differenced levels. For the next step the Johansen cointegration test was employed to check whether a long run relationship exists between the international and domestic market data series. In this study, we use Eviews 8 to test whether long-run relations exist between international grain markets and domestic grain markets. The final step was to employ the MarkovSwitching Autoregressive Model (MS-AR).

A nonlinear model based on Markov Switching process assumes that the change in the dependent variable for a given change in an independent variable depends on the starting value of the independent variable (Wooldridge, 2009). The Markov-Switching process allows regimes (also called states) to occur over several periods of time; in each period $t$ the state is denoted by $R_{t}$; there can be m possible states: $R_{t}=1,2$, ..., m. For example, a simple model with $R=2$ (only 2 regimes), $y_{v_{t}}=v_{t}+\varepsilon_{t}, v_{t}=\mathrm{f}\left(R_{t}\right)$ when $R_{t}=1 ; y_{v_{t}^{\prime}}^{\prime}=v_{t}^{\prime}+\varepsilon^{\prime}{ }_{t}$, $v_{t}^{\prime}=\mathrm{f}\left(R_{t}\right)$ when $R_{t}=2$. The whole process consists of two different equations, for regime 1 and regime 2 individually, when $R=2$.

Within the framework of the Markov-Switching process, we test whether or not the domestic prices would be affected by its previous periods; therefore, the Autoregressive model should be employed to investigate how international grain prices influence the domestic prices. Given this, we employed the MS-AR to analyze the relationship between the price series. The model was specified as follows:

$\left\{\begin{array}{l}P^{D}=\alpha_{0}+\beta_{0} P_{t-1}^{D}+\cdots \beta_{k} P_{t-k}^{D}+\gamma P^{I}+\varepsilon_{t}, \\ P_{t}^{I}=f\left(R_{t}\right) \quad \text { when } R_{t}=1\end{array}\right.$

$\left\{\begin{array}{l}P^{\prime D}=\alpha_{0}^{\prime}+\beta_{0}^{\prime} P_{t-1}^{\prime D}+\cdots \beta_{k}^{\prime} P_{t-k}^{\prime D}+\gamma^{\prime} P^{\prime I}+\varepsilon^{\prime}{ }_{t}, \\ P_{t}^{\prime I}=f\left(R_{t}\right) \quad \text { when } \quad R_{t}=2\end{array}\right.$

where, $P^{D}$ and $P^{D}$ are domestic prices for regime 1 and regime 2 , respectively, $P^{I}$ and $P^{T}$ are international prices and $k$ is a number of lags. Two regimes were set up for each country in this study such that: $R_{t}=1$ for the period before the grain price-hikes, $R_{1}$ hereafter; and $R_{t}=2$ for the period during/after the grain price-hikes, $R_{2}$ hereafter.

\section{Results}

\section{The Results of Unit Root Test and Long-Run Co- Integration Relationship}

The results of the ADF and PP tests show that the grain price series were unstable at the original level, but became stable on the first differenced level except maize price series from Togo (Detailed results may be provided by the authors upon request). Under the Zivot-Andrews Unit Root test (Zivot and Andrews, 1992), the property of the time series data showed that international grain prices had breakpoints for rice, wheat and maize in September, May and July in 2007, respectively. This indicates that international grain prices began to increase sharply in 2007 coinciding with the periods before and during/after the grain price-hikes, namely, $R_{1}$ and $R_{2}$, respectively (Fig. 1). Further, the domestic prices may respond differently from the international prices in $R_{1}$ and $R_{2}$ and this study examines whether or not the domestic grain prices depend on international grain prices which are now divided into two regimes.

Subsequently, the Johansen co-integration test was conducted to investigate the existence of a long run relationship between the price series. The results of the Johansen co-integration test indicate that there are long-run relationships between the international and domestic grain prices in Benin, Cameroon, The Dominican Republic, Guatemala, Nicaragua, Niger, Panama, Sri Lanka and Tunisia for rice data; Armenia, Georgia, Mauritania and Pakistan for the wheat data; and Chad, Guatemala and Nicaragua for the maize (Details are shown in Table 1). If these two variables hold long-run co-integration ships through Johansen's cointegration test, they have some changing trend in long-run term; and they become stable in the same level after the first difference. 
Shuqin Yan et al. / American Journal of Economics and Business Administration 2016, 8 (2): 44.52

DOI: 10.3844/ajebasp.2016.44-52

Table 1. The results of Johansen co-integration test

\begin{tabular}{|c|c|c|c|c|c|c|c|c|c|c|c|c|}
\hline Country & Grains & $\begin{array}{l}\text { Hypoth } \\
\text { esized No. } \\
\text { of CE(s) }\end{array}$ & $\begin{array}{l}\text { Eigen- } \\
\text { value }\end{array}$ & $\begin{array}{l}\text { Trace } \\
\text { statistic }\end{array}$ & $\begin{array}{l}0.05 \\
\text { Critical } \\
\text { value }\end{array}$ & Prob. & $\begin{array}{l}\text { Eigen- } \\
\text { value }\end{array}$ & $\begin{array}{l}\text { Max- } \\
\text { Eigen } \\
\text { statistic }\end{array}$ & $\begin{array}{l}0.05 \\
\text { Critical } \\
\text { value }\end{array}$ & Prob. & Lags & $\begin{array}{l}\text { Coint } \\
\text { egrat- } \\
\text { ingeqn (s) }\end{array}$ \\
\hline \multirow[t]{2}{*}{ Armenia } & \multirow[t]{2}{*}{ Wheat } & None $*$ & 0.145 & 18.628 & 15.495 & 0.016 & 0.145 & 15.786 & 14.265 & 0.029 & \multirow[t]{2}{*}{1} & \multirow[t]{2}{*}{1} \\
\hline & & At most 1 & 0.028 & 2.841 & 3.841 & 0.092 & 0.028 & 2.841 & 3.841 & 0.092 & & \\
\hline \multirow[t]{4}{*}{ Benin } & \multirow[t]{2}{*}{ Rice } & None * & 0.181 & 21.037 & 15.495 & 0.007 & 0.181 & 19.559 & 14.265 & 0.007 & \multirow[t]{2}{*}{1} & \multirow[t]{2}{*}{1} \\
\hline & & At most 1 & 0.015 & 1.478 & 3.841 & 0.224 & 0.015 & 1.478 & 3.841 & 0.224 & & \\
\hline & \multirow[t]{2}{*}{ Maize } & None & 0.085 & 11.877 & 15.495 & 0.163 & 0.085 & 8.996 & 14.265 & 0.287 & \multirow[t]{2}{*}{1} & 0 \\
\hline & & At most 1 & 0.028 & 2.881 & 3.841 & 0.090 & 0.028 & 2.881 & 3.841 & 0.090 & & \\
\hline Brazil & Rice & None $*$ & 0.123 & 18.241 & 15.495 & 0.019 & 0.123 & 13.131 & 14.265 & 0.075 & 2 & 0 \\
\hline & & At most $1 *$ & 0.050 & 5.110 & 3.841 & 0.024 & 0.050 & 5.110 & 3.841 & 0.024 & & \\
\hline & Wheat & None $*$ & 0.111 & 16.164 & 15.495 & 0.040 & 0.111 & 11.794 & 14.265 & 0.119 & 1 & 0 \\
\hline & & At most $1 *$ & 0.043 & 4.369 & 3.841 & 0.037 & 0.043 & 4.369 & 3.841 & 0.037 & & \\
\hline Burundi & Rice & None & 0.100 & 12.548 & 15.495 & 0.133 & 0.100 & 9.122 & 14.265 & 0.276 & 1 & 0 \\
\hline & & At most $1 *$ & 0.039 & 3.426 & 3.841 & 0.064 & 0.039 & 3.426 & 3.841 & 0.064 & & \\
\hline & Wheat & None & 0.119 & 9.909 & 15.495 & 0.288 & 0.119 & 8.979 & 14.265 & 0.288 & 1 & 0 \\
\hline & & At most 1 & 0.013 & 0.931 & 3.841 & 0.335 & 0.013 & 0.931 & 3.841 & 0.335 & & \\
\hline & Maize & None & 0.108 & 12.58 & 15.495 & 0.131 & 0.108 & 9.937 & 14.265 & 0.216 & 1 & 0 \\
\hline & & At most 1 & 0.030 & 2.643 & 3.841 & 0.104 & 0.030 & 2.643 & 3.841 & 0.104 & & \\
\hline Cameroon & Rice & None * & 0.285 & 34.098 & 15.495 & 0.000 & 0.285 & 31.916 & 14.265 & 0.000 & 1 & 1 \\
\hline & & At most 1 & 0.023 & 2.182 & 3.841 & 0.140 & 0.023 & 2.182 & 3.841 & 0.140 & & \\
\hline & Wheat & None & 0.067 & 12.38 & 15.495 & 0.140 & 0.067 & 6.695 & 14.265 & 0.526 & 1 & 0 \\
\hline & & At most $1 *$ & 0.057 & 5.685 & 3.841 & 0.017 & 0.057 & 5.685 & 3.841 & 0.017 & & \\
\hline & Maize & None $*$ & 0.135 & 15.675 & 15.495 & 0.047 & 0.135 & 13.682 & 14.265 & 0.062 & 1 & 0 \\
\hline & & At most 1 & 0.021 & 1.993 & 3.841 & 0.158 & 0.021 & 1.993 & 3.841 & 0.158 & & \\
\hline Cape Verde & Rice & None & 0.127 & 15.995 & 15.495 & 0.042 & 0.127 & 11.995 & 14.265 & 0.111 & 1 & 0 \\
\hline & & At most $1 *$ & 0.044 & 4.000 & 3.841 & 0.046 & 0.044 & 4.000 & 3.841 & 0.046 & & \\
\hline & Wheat & None $*$ & 0.119 & 18.229 & 15.495 & 0.019 & 0.119 & 11.272 & 14.265 & 0.141 & 1 & 0 \\
\hline & & At most $1 *$ & 0.075 & 6.957 & 3.841 & 0.008 & 0.075 & 6.957 & 3.841 & 0.008 & & \\
\hline & Maize & None & 0.107 & 13.032 & 15.495 & 0.114 & 0.107 & 9.968 & 14.265 & 0.214 & 1 & 0 \\
\hline & & At most 1 & 0.034 & 3.064 & 3.841 & 0.080 & 0.034 & 3.064 & 3.841 & 0.080 & & \\
\hline Chad & Rice & None & 0.132 & 17.895 & 15.495 & 0.021 & 0.132 & 13.153 & 14.265 & 0.074 & 1 & 0 \\
\hline & & At most 1 & 0.05 & 4.742 & 3.841 & 0.029 & 0.050 & 4.742 & 3.841 & 0.029 & & \\
\hline & Maize & None * & 0.172 & 21.79 & 15.495 & 0.005 & 0.172 & 18.845 & 14.265 & 0.009 & 1 & 1 \\
\hline & & At most 1 & 0.029 & 2.945 & 3.841 & 0.086 & 0.029 & 2.945 & 3.841 & 0.086 & & \\
\hline Dominican & Rice & None $*$ & 0.171 & 21.291 & 15.495 & 0.006 & 0.171 & 16.347 & 14.265 & 0.023 & 2 & 2 \\
\hline & & At most $1 *$ & 0.055 & 4.945 & 3.841 & 0.026 & 0.055 & 4.945 & 3.841 & 0.026 & & \\
\hline & Maize & None & 0.133 & 15.191 & 15.495 & 0.056 & 0.133 & 12.573 & 14.265 & 0.091 & 1 & 0 \\
\hline & & At most 1 & 0.029 & 2.617 & 3.841 & 0.106 & 0.029 & 2.617 & 3.841 & 0.106 & & \\
\hline Georgia & Wheat & None * & 0.248 & 32.358 & 15.495 & 0.000 & 0.248 & 28.749 & 14.265 & 0.000 & 1 & 1 \\
\hline & & At most 1 & 0.035 & 3.609 & 3.841 & 0.058 & 0.035 & 3.609 & 3.841 & 0.058 & & \\
\hline Guatemala & Rice & None & 0.251 & 30.578 & 15.495 & 0.000 & 0.251 & 28.956 & 14.265 & 0.000 & 1 & 1 \\
\hline & & At most 1 & 0.016 & 1.621 & 3.841 & 0.203 & 0.016 & 1.621 & 3.841 & 0.203 & & \\
\hline & Maize & None * & 0.141 & 16.002 & 15.495 & 0.042 & 0.141 & 15.212 & 14.265 & 0.035 & 1 & 1 \\
\hline & & At most 1 & 0.008 & 0.79 & 3.841 & 0.374 & 0.008 & 0.790 & 3.841 & 0.374 & & \\
\hline Kyrgyzstan & Wheat & None $*$ & 0.116 & 17.114 & 15.495 & 0.028 & 0.116 & 12.439 & 14.265 & 0.095 & 1 & 0 \\
\hline & & At most $1 *$ & 0.045 & 4.675 & 3.841 & 0.031 & 0.045 & 4.675 & 3.841 & 0.031 & & \\
\hline Laos & Rice & None & 0.159 & 12.102 & 15.495 & 0.152 & 0.159 & 11.392 & 14.265 & 0.136 & 1 & 0 \\
\hline & & At most 1 & 0.011 & 0.710 & 3.841 & 0.400 & 0.011 & 0.710 & 3.841 & 0.400 & & \\
\hline Madagascar & Rice & None & 0.121 & 13.417 & 15.495 & 0.100 & 0.121 & 11.070 & 14.265 & 0.151 & 3 & 0 \\
\hline & & At most 1 & 0.027 & 2.348 & 3.841 & 0.126 & 0.027 & 2.348 & 3.841 & 0.126 & & \\
\hline Mauritania & Rice & None & 0.069 & 12.097 & 15.495 & 0.152 & 0.069 & 7.182 & 14.265 & 0.468 & 1 & 0 \\
\hline & & At most $1 *$ & 0.048 & 4.914 & 3.841 & 0.027 & 0.048 & 4.914 & 3.841 & 0.027 & & \\
\hline & Wheat & None $*$ & 0.188 & 24.152 & 15.495 & 0.002 & 0.188 & 20.659 & 14.265 & 0.004 & 1 & 1 \\
\hline & & At most 1 & 0.035 & 3.493 & 3.841 & 0.062 & 0.035 & 3.493 & 3.841 & 0.062 & & \\
\hline Nepal & Rice & None $*$ & 0.132 & 18.902 & 15.495 & 0.015 & 0.132 & 13.629 & 14.265 & 0.063 & 2 & 0 \\
\hline & & At most $1 *$ & 0.053 & 5.273 & 3.841 & 0.022 & 0.053 & 5.273 & 3.841 & 0.022 & & \\
\hline & Wheat & None & 0.103 & 13.043 & 15.495 & 0.113 & 0.103 & 10.122 & 14.265 & 0.204 & 2 & 0 \\
\hline & & At most 1 & 0.031 & 2.921 & 3.841 & 0.087 & 0.031 & 2.921 & 3.841 & 0.087 & & \\
\hline Nicaragua & Rice & None * & 0.341 & 44.747 & 15.495 & 0.000 & 0.341 & 42.131 & 14.265 & 0.000 & 1 & 1 \\
\hline & & At most 1 & 0.026 & 2.616 & 3.841 & 0.106 & 0.026 & 2.616 & 3.841 & 0.106 & & \\
\hline & Maize & None * & 0.138 & 17.286 & 15.495 & 0.027 & 0.138 & 14.795 & 14.265 & 0.041 & 1 & 1 \\
\hline & & At most $1 *$ & 0.025 & 2.491 & 3.841 & 0.115 & 0.025 & 2.491 & 3.841 & 0.115 & & \\
\hline Niger & Rice & None $*$ & 0.177 & 18.615 & 15.495 & 0.016 & 0.177 & 16.753 & 14.265 & 0.020 & 1 & 1 \\
\hline & & At most 1 & 0.021 & 1.862 & 3.841 & 0.172 & 0.021 & 1.862 & 3.841 & 0.172 & & \\
\hline & Maize & None & 0.113 & 12.931 & 15.495 & 0.117 & 0.113 & 10.166 & 14.265 & 0.201 & 2 & 0 \\
\hline & & At most 1 & 0.032 & 2.764 & 3.841 & 0.096 & 0.032 & 2.764 & 3.841 & 0.096 & & \\
\hline
\end{tabular}


Shuqin Yan et al. / American Journal of Economics and Business Administration 2016, 8 (2): 44.52 DOI: 10.3844/ajebasp.2016.44-52

\begin{tabular}{|c|c|c|c|c|c|c|c|c|c|c|c|c|}
\hline \multirow[t]{4}{*}{ Pakistan } & \multirow[t]{2}{*}{ Rice } & None * & 0.125 & 16.308 & 15.495 & 0.038 & 0.125 & 11.896 & 14.265 & 0.115 & \multirow[t]{2}{*}{1} & \multirow[t]{2}{*}{0} \\
\hline & & At most $1 *$ & 0.048 & 4.413 & 3.841 & 0.036 & 0.048 & 4.413 & 3.841 & 0.036 & & \\
\hline & \multirow[t]{2}{*}{ Wheat } & None $*$ & 0.192 & 24.582 & 15.495 & 0.002 & 0.192 & 18.594 & 14.265 & 0.010 & \multirow[t]{2}{*}{2} & \multirow[t]{2}{*}{2} \\
\hline & & At most $1 *$ & 0.067 & 5.988 & 3.841 & 0.014 & 0.067 & 5.988 & 3.841 & 0.014 & & \\
\hline \multirow[t]{4}{*}{ Panama } & \multirow[t]{2}{*}{ Rice } & None * & 0.196 & 21.858 & 15.495 & 0.005 & 0.196 & 17.662 & 14.265 & 0.014 & \multirow[t]{2}{*}{2} & \multirow[t]{2}{*}{2} \\
\hline & & At most $1 *$ & 0.050 & 4.196 & 3.841 & 0.041 & 0.050 & 4.196 & 3.841 & 0.041 & & \\
\hline & \multirow[t]{2}{*}{ Maize } & None & 0.101 & 10.396 & 15.495 & 0.252 & 0.101 & 8.809 & 14.265 & 0.302 & \multirow[t]{2}{*}{1} & \multirow[t]{2}{*}{0} \\
\hline & & At most 1 & 0.019 & 1.587 & 3.841 & 0.208 & 0.019 & 1.587 & 3.841 & 0.208 & & \\
\hline \multirow[t]{6}{*}{ Peru } & \multirow[t]{2}{*}{ Rice } & None & 0.084 & 12.426 & 15.495 & 0.138 & 0.084 & 8.789 & 14.265 & 0.304 & \multirow[t]{2}{*}{1} & \multirow[t]{2}{*}{0} \\
\hline & & At most $1 *$ & 0.036 & 3.637 & 3.841 & 0.057 & 0.036 & 3.637 & 3.841 & 0.057 & & \\
\hline & \multirow[t]{2}{*}{ Wheat } & None & 0.082 & 10.498 & 15.495 & 0.244 & 0.082 & 8.602 & 14.265 & 0.321 & \multirow[t]{2}{*}{1} & \multirow[t]{2}{*}{0} \\
\hline & & At most 1 & 0.019 & 1.896 & 3.841 & 0.169 & 0.019 & 1.896 & 3.841 & 0.169 & & \\
\hline & \multirow[t]{2}{*}{ Maize } & None & 0.080 & 10.351 & 15.495 & 0.255 & 0.080 & 8.320 & 14.265 & 0.347 & \multirow[t]{2}{*}{1} & \multirow[t]{2}{*}{0} \\
\hline & & At most 1 & 0.020 & 2.031 & 3.841 & 0.154 & 0.020 & 2.031 & 3.841 & 0.154 & & \\
\hline \multirow[t]{4}{*}{ Philippines } & \multirow[t]{2}{*}{ Rice } & None * & 0.132 & 15.522 & 15.495 & 0.050 & 0.132 & 13.920 & 14.265 & 0.057 & \multirow[t]{2}{*}{4} & \multirow[t]{2}{*}{0} \\
\hline & & At most 1 & 0.016 & 1.602 & 3.841 & 0.206 & 0.016 & 1.602 & 3.841 & 0.206 & & \\
\hline & \multirow[t]{2}{*}{ Maize } & None & 0.053 & 8.056 & 15.495 & 0.460 & 0.053 & 5.451 & 14.265 & 0.684 & 1 & 0 \\
\hline & & At most 1 & 0.025 & 2.605 & 3.841 & 0.107 & 0.025 & 2.605 & 3.841 & 0.107 & & \\
\hline Sri Lanka & Rice & None $*$ & 0.234 & 29.098 & 15.495 & 0.000 & 0.234 & 22.115 & 14.265 & 0.002 & 1 & 2 \\
\hline & & At most $1 *$ & 0.081 & 6.983 & 3.841 & 0.008 & 0.081 & 6.983 & 3.841 & 0.008 & & \\
\hline & Wheat & None $*$ & 0.142 & 18.611 & 15.495 & 0.016 & 0.142 & 12.748 & 14.265 & 0.086 & 1 & 0 \\
\hline & & At most $1 *$ & 0.068 & 5.863 & 3.841 & 0.016 & 0.068 & 5.863 & 3.841 & 0.016 & & \\
\hline Togo & Rice & None & 0.048 & 8.153 & 15.495 & 0.449 & 0.048 & 4.799 & 14.265 & 0.767 & 2 & 0 \\
\hline & & At most 1 & 0.034 & 3.354 & 3.841 & 0.067 & 0.034 & 3.354 & 3.841 & 0.067 & & \\
\hline & Maize & None $*$ & 0.140 & 17.758 & 15.495 & 0.022 & 0.140 & 15.214 & 14.265 & 0.035 & 1 & 1 \\
\hline & & At most 1 & 0.025 & 2.544 & 3.841 & 0.111 & 0.025 & 2.544 & 3.841 & 0.111 & & \\
\hline Tunisia & Rice & None & 0.375 & 47.479 & 15.495 & 0.000 & 0.375 & 45.079 & 14.265 & 0.000 & 1 & 1 \\
\hline & & At most 1 & 0.025 & 2.401 & 3.841 & 0.121 & 0.025 & 2.401 & 3.841 & 0.121 & & \\
\hline
\end{tabular}

Note: The results were calculated by author using the software, Eviews $8.0 .{ }^{*}$ denotes rejection of the hypothesis at the 0.05 level

The Results of Markov-Switching Autoregressive Model (MS-AR)

The results from the Zivot-Andrew unit root test indicate that international grain prices had one breakpoint in 2007 for grains, which is correspondent to the beginning of the grain price-hikes period; this led us to define the period into two regimes $\left(R_{1}\right.$ and $\left.R_{2}\right)$. The implication of this is that the domestic prices respond differently to the international prices between $R_{1}$ and $R_{2}$. Subsequently, it may be possible to assume that the domestic grain prices depend on the change in international grain prices, which are separated into two different regimes. Accordingly, this study employs the MS-AR for the empirical analysis with out conducting the specification test following Hamilton (1996).

Guided by the Akaike Information Criterion (AIC) and Schwarz Criterion (SC), we selected the lag numbers, whose values of AIC and SC were the smallest. According to the results in Table 2, the estimated parameters for wheat of $\operatorname{Ln} \mathrm{P}_{\mathrm{I}}$ (international wheat prices) in Armenia at 0.060 and 0.094 for $R_{1}$ and $R_{2}$, respectively, are statistically significant. The results indicate that the international wheat prices significantly and positively influence wheat prices in Armenia in $R_{1}$ and $R_{2}$ : When the former increases by $1 \%$, the latter increases by $0.060 \%$ in $R_{1}$ and $0.094 \%$ in $R_{2}$. Therefore, we concluded that for wheat in Armenia, international wheat prices have a positive influence on domestic prices both in these two regimes; however, the magnitude of influence in $R_{2}$ may be greater than that in $R_{1}$. Food security and Agriculture Highlights of FAO (2011) reports that the cereal imports in 2005-2006 were below 330,000 tonnes level, but the imports increased to 542,000 tonnes level in 2007 and reduced to 382,000 tonnes level in 2008, with an increasing trend afterward in Armenia. The imports in $R_{2}$ were larger than $R_{1}$ and the domestic wheat prices in Armenia might have been mainly influenced by the international wheat market; therefore, this may be why the influence in $R_{2}$ was greater than that in $R_{1}$. Performing the same analytical procedure for wheat in other countries, including Georgia, Mauritania and Pakistan, the international wheat prices have a positive influence on domestic prices in both regimes. The results indicate that the influence in $R_{2}$ is greater than or equal to those in $R_{1}$.

The parameter estimation for rice of $L n P_{I}$ (international rice prices) in Cameroon at 0.132 and 0.083 in $R_{1}$ and $R_{2}$, respectively, are statistically significant. It was also found that international rice prices show statistically significant but contradicting effects on the domestic rice prices in 9 countries i.e., in Benin, Cameroon, Niger and Tunisia, the in fluencies in $R_{2}$ are much smaller than that in $R_{1}$; in Nicaragua and Guatemala, the effects in $R_{2}$ is greater than those in $R_{1}$; and in the Dominican Republic, Panama and Sri Lanka international rice prices have no significant effects on the domestic rice prices in both regimes.

Through the estimated results of $\operatorname{Ln} P_{I}$ (international maize prices) for maize in Chad at 0.080 and 0.041 in $R_{1}$ and $R_{2}$, respectively, which were statistically significant, 
we understood that its domestic maize prices may be significantly influenced by international maize prices in both regimes, $R_{1}$ and $R_{2}$. With the same analytical steps for maize in Chad, on the other hand, it was found that the effect of the international prices may also be positive in Guatemala and Nicaragua and the influence in $R_{2}$ is also smaller than those in $R_{1}$. The reason for these may be that the government already took effective policy intervention during and after price crisis. For example, Central American Emergency implemented some measures to confront the rise in prices and possible scarcity of the four products such as rice, beans, corn and sorghum (FAO, 2014b). Guatemala took a policy of the tariff-rate quota system on selected food staples in 2008 and MiComunidad Produce in 2009 (FAO, 2014b).

Totally, in The Dominican Republic, Panama and Sri Lanka for the rice series, the results show that there were no significant effects of international prices on domestic prices in both $R_{1}$ and $R_{2}$. That may be because they are relatively independent from international markets. An overview of the historical data from these countries on production, consumption, imports and exports, we found that the self-sufficiency rates of rice are more than $75 \%$ in these three countries (Ito, 2014). For the other countries, which heavily depend on international trade, the rates of imported grain to the entire domestic consumption are greater than $60 \%$. Therefore, these developing countries would be influenced more or less by international grain prices.

The parameter estimates for maize of $L n_{P D}(-1)$ (domestic maize price last month) and $L n_{P D(-2)}$ (domestic maize price two months before) in Chad are 1.483 and 0.915 in $R_{1}$ and 1.053 and -0.202 in $R_{2}$, respectively. Though the estimated parameters are opposite in signs between the 2 lagging periods, namely, positive to the last month and negative to the previous two months in both of these two periods (regimes), the total effects are positive indicating that the positive effects from the prices in the previous months maybe over whelrning the negative effects two months before.

Table 2. The results of Markov-Switching Autoregressive (MS-AR) model

\begin{tabular}{|c|c|c|c|c|c|c|c|}
\hline \multirow[b]{2}{*}{ Grain } & \multirow[b]{2}{*}{ Country } & \multicolumn{6}{|c|}{ MS-ARModel } \\
\hline & & & $\operatorname{Ln} P_{I}$ & $\operatorname{Ln} P_{D(-1)}$ & $\operatorname{Ln} P_{D(-2)}$ & $\operatorname{Ln} P_{D(-3)}$ & $\mathrm{C}$ \\
\hline \multirow[t]{8}{*}{ Wheat } & Armenia & $\mathrm{R}_{1}$ & $0.060^{* * *}$ & $1.208_{* * *}^{* * *}$ & -0.249 & & $0.058_{* * *}$ \\
\hline & & $\mathrm{R}_{2}$ & $0.094^{* * *}$ & $1.181^{* * *}$ & $-0.295^{* * *}$ & & $0.203^{* * *}$ \\
\hline & Georgia & $\mathrm{R}_{1}$ & $0.128^{* *}$ & $0.772^{* * *}$ & 0.082 & & 0.265 \\
\hline & & $\mathrm{R}_{2}$ & $0.176^{* * *}$ & $0.722^{* * *}$ & 0.102 & & 0.221 \\
\hline & Mauritania & $\mathrm{R}_{1}$ & $0.029^{*}$ & 0.373 & $0.546^{* *}$ & & 0.537 \\
\hline & & $\mathrm{R}_{2}$ & $0.676^{* * *}$ & $-0.517^{* * *}$ & 0.302 & & $4.084^{* * *}$ \\
\hline & Pakistan & $\mathrm{R}_{1}$ & $0.071^{*}$ & $1.201^{* * *}$ & -0.716 & 0.438 & 0.048 \\
\hline & & $\mathrm{R}_{2}$ & $0.071^{* * *}$ & $1.531^{* * *}$ & $-0.573^{* * *}$ & $0.515^{* * *}$ & $0.192^{* * *}$ \\
\hline \multirow[t]{12}{*}{ Rice } & \multirow[t]{2}{*}{$\begin{array}{l}\text { The Dominican } \\
\text { Republic }\end{array}$} & $\mathrm{R}_{1}$ & 0.020 & $2.035^{*}$ & -1.746 & 0.714 & -0.190 \\
\hline & & $\mathrm{R}_{2}$ & 0.033 & $0.748^{*}$ & 0.216 & -0.094 & $0.613^{* * *}$ \\
\hline & \multirow[t]{2}{*}{ Panama } & $\mathrm{R}_{1}$ & 0.012 & $0.162^{* *}$ & $0.116^{*}$ & $0.012^{* * *}$ & -5.769 \\
\hline & & $\mathrm{R}_{2}$ & 0.022 & -0.065 & $-0.261^{* *}$ & 0.038 & -2.476 \\
\hline & \multirow[t]{2}{*}{ Nicaragua } & $\mathrm{R}_{1}$ & $0.050^{* * *}$ & $1.217^{* * *}$ & $-0.271^{*}$ & & $0.140^{* * *}$ \\
\hline & & $\mathrm{R}_{2}$ & $0.055^{* * *}$ & $1.069^{* * *}$ & -0.193 & & $0.418^{* * *}$ \\
\hline & \multirow[t]{2}{*}{ Tunisia } & $\mathrm{R}_{1}$ & $0.177^{* *}$ & $0.811^{* * *}$ & 0.172 & & -0.811 \\
\hline & & $\mathrm{R}_{2}$ & $0.005^{*}$ & 0.993 & -0.016 & & 0.123 \\
\hline & \multirow[t]{2}{*}{ Benin } & $\mathrm{R}_{1}$ & $0.046^{* *}$ & $0.858^{* * *}$ & 0.077 & & 0.155 \\
\hline & & $\mathrm{R}_{2}$ & 0.056 & 0.810 & 0.163 & & 0.189 \\
\hline & \multirow[t]{2}{*}{ Cameroon } & $\mathrm{R}_{1}$ & $0.132^{* *}$ & $0.972^{*}$ & -0.096 & & 0.955 \\
\hline & & $\mathrm{R}_{2}$ & $0.083^{*}$ & 0.969 & $-0.219^{* * *}$ & & 1.135 \\
\hline & \multirow[t]{2}{*}{ Sri Lanka } & $\mathrm{R}_{1}$ & 0.015 & 1.385 & $-0.460^{* *}$ & & 0.371 \\
\hline & & $\mathrm{R}_{2}$ & 0.030 & $1.480_{* * *}$ & $-0.295_{* * *}$ & & 0.761 \\
\hline & \multirow[t]{2}{*}{ Guatemala } & $\mathrm{R}_{1}$ & $0.046_{* * *}$ & $1.624^{* * * *}$ & $-0.304^{* * * *}$ & & 0.088 \\
\hline & & $\mathrm{R}_{2}$ & $0.028_{* * * *}^{* * *}$ & $1.460^{* * *}$ & $-0.497^{* * *}$ & & 0.059 \\
\hline & \multirow[t]{2}{*}{ Niger } & $\mathrm{R}_{1}$ & $0.049^{* *}$ & $0.900^{* * *}$ & -0.010 & & 0.447 \\
\hline & & $\mathrm{R}_{2}$ & -0.020 & $1.118^{* * *}$ & -0.109 & & 0.051 \\
\hline \multirow[t]{6}{*}{ Maize } & \multirow[t]{2}{*}{ Guatemala } & $\mathrm{R}_{1}$ & $0.081^{*}$ & 1.047 & $-0.157^{* * *}$ & & 0.263 \\
\hline & & $\mathrm{R}_{2}$ & 0.077 & $1.050^{* * *}$ & $-0.164^{* * *}$ & & 0.333 \\
\hline & \multirow[t]{2}{*}{ Chad } & $\mathrm{R}_{1}$ & $0.080^{*}$ & $1.483^{* * *}$ & $-0.915^{* * *}$ & & 2.059 \\
\hline & & $\mathrm{R}_{2}$ & $0.041^{*}$ & $1.053^{* * *}$ & $-0.202^{* *}$ & & $0.711^{* * *}$ \\
\hline & \multirow[t]{2}{*}{ Nicaragua } & $\mathrm{R}_{1}$ & $0.075^{* *}$ & $0.934^{* * *}$ & $-0.383^{* *}$ & & $1.940^{* * *}$ \\
\hline & & $\mathrm{R}_{2}$ & 0.039 & $0.614^{* * *}$ & $0.539^{* * *}$ & & $-0.955^{* * *}$ \\
\hline
\end{tabular}

Note: (1) $P_{D}$ is domestic prices, $P_{I}$ is international prices, (-1), (-2) and (-3) is number of lags; (2) Ln is natural logarithmic form. (3) ${ }^{* * *}$ and ${ }^{* * *}$ denotes 10,5 and $1 \%$ significant, respectively 
Performing the same analytical procedure for $\operatorname{Ln} P_{D(-1)}$, $\operatorname{Ln} P_{D(-2)}$ and $\operatorname{Ln} P_{D(-3)}$ for the other countries, the results indicated that the influences of the domestic prices during the previous months on the domestic current prices were positive in $R_{1}$ and $R_{2}$, except $R_{2}$ in Mauritania. Meanwhile, the effects of the domestic prices two months previous on the current prices were negative in several countries; however, the total effects of domestic prices in previous periods on current domestic prices were basically positive. The total effects in $R_{1}$ of Sri Lanka and $R_{2}$ of Panama, Cameroon and Mauritania were negative while the coefficients of $\operatorname{Ln} P_{D}(-1)$ which are expected to be most influential were not significant in those countries.

The results shown in Table 2 are classified in Table 3 according to each grain being the staple-food or not as well as the levels of self-sufficiency rates. For wheat, the influences of international prices on domestic market in $R_{1}$ were equal to those in $R_{2}$ possibly reflecting being a high self-sufficient rate country such as Pakistan. In low self-sufficient rate countries including Armenia, Mauritania and Georgia may be with smaller influence in $R_{1}$ than those in $R_{2}$; and their total effects of domestic price in previous periods on the current term are positive except $R_{2}$ in Mauritania. For maize, influences in $R_{1}$ were greater than those in $R_{2}$ in high self-sufficient rate countries such as Chad, Nicaragua and Guatemala; and their total effects of domestic price in previous periods on current term are positive.

Table 3. Characteristics in MS-AR model results for the situation of grain in developing countries

\begin{tabular}{|c|c|c|c|c|c|c|}
\hline Grain & Country & $\begin{array}{l}\text { Staple } \\
\text { food }^{(1)}\end{array}$ & $\begin{array}{l}\text { Self- } \\
\text { sufficient } \\
\text { rate }^{(2)}\end{array}$ & $\begin{array}{l}\operatorname{Ln} P_{I}: R_{1} \\
\operatorname{Vs} R_{2}^{(3)}\end{array}$ & Regime & $\begin{array}{l}\text { Total effects: } \\
\operatorname{Ln} P_{D(-1)}+\operatorname{Ln} P_{D(-2)} \\
\left(+\operatorname{Ln} P_{D(-3)}\right)\end{array}$ \\
\hline \multirow[t]{8}{*}{ Wheat } & \multirow[t]{2}{*}{ Pakistan } & \multirow[t]{2}{*}{ Yes } & \multirow[t]{2}{*}{$102.14 \%$} & \multirow[t]{2}{*}{$0.071^{*}=0.071^{* * *}$} & $\mathrm{R}_{1}$ & Positive \\
\hline & & & & & $\mathrm{R}_{2}$ & Positive \\
\hline & \multirow[t]{2}{*}{ Armenia } & \multirow[t]{2}{*}{ Yes } & \multirow[t]{2}{*}{$43.4 \%$} & \multirow[t]{2}{*}{$0.060^{*}<0.094^{* * *}$} & $\mathrm{R}_{1}$ & Positive \\
\hline & & & & & $\mathrm{R}_{2}$ & Positive \\
\hline & \multirow[t]{2}{*}{ Mauritania } & \multirow[t]{2}{*}{ Yes } & \multirow[t]{2}{*}{$0 \%$} & \multirow[t]{2}{*}{$0.029<0.676^{* * *}$} & $\mathrm{R}_{1}$ & Positive \\
\hline & & & & & $\mathrm{R}_{2}$ & Negative \\
\hline & \multirow[t]{2}{*}{ Georgia } & \multirow[t]{2}{*}{ Yes } & \multirow[t]{2}{*}{ NA } & \multirow[t]{2}{*}{$0.128^{* *}<0.176^{* * *}$} & $\mathrm{R}_{1}$ & Positive \\
\hline & & & & & $\mathrm{R}_{2}$ & Positive \\
\hline \multirow[t]{18}{*}{ Rice } & \multirow[t]{2}{*}{ Sri Lanka } & \multirow[t]{2}{*}{ Yes } & \multirow[t]{2}{*}{$100 \%$} & \multirow[t]{2}{*}{$0.015 \& 0.030$} & $\mathrm{R}_{1}$ & Negative \\
\hline & & & & & $\mathrm{R}_{2}$ & NA \\
\hline & \multirow[t]{2}{*}{$\begin{array}{l}\text { The Dominican } \\
\text { Republic }\end{array}$} & \multirow[t]{2}{*}{ Yes } & \multirow[t]{2}{*}{$95.7 \%$} & \multirow[t]{2}{*}{$0.020 \& 0.033$} & $\mathrm{R}_{1}$ & Positive \\
\hline & & & & & $\mathrm{R}_{2}$ & Positive \\
\hline & \multirow[t]{2}{*}{ Panama } & \multirow[t]{2}{*}{ Yes } & \multirow[t]{2}{*}{$75.9 \%$} & $0.012 \& 0.022$ & $\mathrm{R}_{1}$ & Positive \\
\hline & & & & & $\mathrm{R}_{2}$ & Negative \\
\hline & Nicaragua & Yes & $72.3 \%$ & $0.050^{* * *}<0.055^{* * *}$ & $\mathrm{R}_{1}$ & Positive \\
\hline & & & & & $\mathrm{R}_{2}$ & Positive \\
\hline & Tunisia & Yes & $43.1 \%$ & $0.177^{*} \square 0.005^{*}$ & $\mathrm{R}_{1}$ & Positive \\
\hline & & & & & $\mathrm{R}_{2}$ & NA \\
\hline & Benin & Yes & $28.6 \%$ & $0.046^{* *}[0.056$ & $\mathrm{R}_{1}$ & Positive \\
\hline & & & & & $\mathrm{R}_{2}$ & NA \\
\hline & Niger & Yes & $24.8 \%$ & $0.049^{* *} \square-0.020$ & $\mathrm{R}_{1}$ & Positive \\
\hline & & & & & $\mathrm{R}_{2}$ & Positive \\
\hline & Guatemala & $3 \%$ & $24.1 \%$ & $0.046<0.028^{* * *}$ & $\mathrm{R}_{1}$ & Positive \\
\hline & & & & & $\mathrm{R}_{2}$ & Positive \\
\hline & Cameroon & $24.3 \%$ & $13.6 \%$ & $0.132^{* *} \square 0.083^{*}$ & $\mathrm{R}_{1}$ & Positive \\
\hline & & & & & $\mathrm{R}_{2}$ & Negative \\
\hline Maize & Chad & Yes & $92.1 \%$ & $\left.0.080^{*}\right] 0.041^{*}$ & $\mathrm{R}_{1}$ & Positive \\
\hline & & & & & $\mathrm{R}_{2}$ & Positive \\
\hline & Nicaragua & Yes & $80.1 \%$ & $\left.0.075^{* *}\right] 0.039$ & $\mathrm{R}_{1}$ & Positive \\
\hline & & & & & $\mathrm{R}_{2}$ & Positive \\
\hline & Guatemala & Yes & $69.9 \%$ & $0.081^{*} \square 0.077$ & $\mathrm{R}_{1}$ & Positive \\
\hline & & & & & $\mathrm{R}_{2}$ & Positive \\
\hline
\end{tabular}

Note: Table 3 here is for classified expression of the estimated coefficients in Table 2.

(1) Staple food: Rice, wheat and maize whether staple food or not, data source: Safari the Global, Cultural Information, Staple Foods and some other document.

(2) Self-Sufficient rates are quoted from Ito (2014), NA indicates no data;

(3) When the coefficients are not significant in both of two regimes, a " $\&$ " issued like $0.012 \& 0.022$ in Panama; When only one regime is not significant, it is assumed to be equal to 0 , and expressed like $0.046^{* *} \square 0.056$ in Benin.

(4)Total effect summaries are from Table 2; an NA implied that the coefficients are not significant. 
For rice, influences in $R_{2}$ were greater than those in $R_{1}$ in high self-sufficient rate countries such as Nicaragua and the influence of international prices on domestic market were not statistically significant in $R_{1}$ and $R_{2}$ for Sri Lanka, the Dominican Republic and Panama. On the other hand, influences in $R_{1}$ were greater than those in $R_{2}$ in low self-sufficient rate countries except Guatemala, where rice is not staple food; and their total effects of domestic price in previous periods on current term are positive except $R_{1}$ in Sri Lanka and $R_{2}$ in Panama and Cameroon.

There are two types of countries among the 24 countries in this study. The first type is for those countries that are self-sufficient or isolated from the international grain market in food supply. The domestic prices in these countries may not be significantly affected by international grain prices throughout the periods. They are Sri Lanka, The Dominican Republic and Panama for rice (Table 3).

The second type is those where grain consumptions depend mainly on importsortrade with other countries. They are influenced significantly by international grain prices. They are Tunisia, Benin, Niger, Guatemala and Cameroon for rice and Armenia, Mauritania and Georgia for wheat. Overall, in this study, the influences from the international grain prices on domestic grain prices are less in $R_{2}$ relative to those in $R_{1}$ in these countries where rice or maize are staple food. However, the influences for those countries in which wheat are staple food are lager or equal in $R_{2}$ relative to those in $R_{1}$, such as Armenia, Georgia, Mauritania and Pakistan. In the case of Pakistan, which may not belong to either type, the self-sufficient rate of wheat is as larger as $102 \%$. Its exports account for around 5\% of total domestic production and imports account for $3.2 \%$ of domestic production of wheat during these periods. Although the rates of exports and imports are not large, wheat price in Pakistan may be affected by the international market and the government would not take any measures to control it.

\section{Discussion}

Among the existing papers that studied the topic of food price transmissions from international markets to domestic markets using linear models to analyze, Robles and Cooke (2009; Robles, 2011) found positive transmission effects in the case of wheat in Latin American countries and in two out of three Asian countries using an Autoregressive Distributed Lag (ADL) model; Minot (2010) examined the degree to which changes in world food markets influence the price of staple foods in Sub-Saharan African countries using Vector Error Correction Model (VECM) and suggested that only one fifth of the considered domestic price series had a long-run relationship to international prices and that rice prices seemed to be more integrated than maize prices. Cao et al. (2013) studied the grain price transmission from international grain markets to Chinese grain markets using the Johansen co-integration test, VECM model and Granger-causality test. In these existing studies, they assumed the fluctuation of food prices to be one whole process and then they analyzed the situation of price transmissions using different models. Those results demonstrated how the international grain prices influenced the domestic grain prices in the whole process of price fluctuation in different countries or regions.

Meanwhile, in this study, a nonlinear model, MarkovSwitching Auto-regressive Model, was employed to analyze whether or not the international grains prices performed for the two different regimes (before and during/after price-hikes) and the domestic grain prices were likely to be influenced differently by the international grain prices in these two regimes. The results in this study should directly reflect different influences of international grain prices on the domestic food prices before and during/after grain price hikes. Understanding the different influences of international grain prices on domestic grain prices in these two different regimes is critical to help design better global, regional and domestic food policies to inhibit any problematic influences from international grain markets. This study should contribute further to the existing research in the field of price transmission.

\section{Conclusion}

In this study, it was found that, during the entire study period of domestic grain prices in the developing countries, international grain prices basically had a positive influence on domestic grain prices in both $R_{1}$ and $R_{2}$ (namely, before and during/after the grain pricehikes, respectively). For the effects of domestic prices in previous months, they were indicated to have positive influences on current domestic grain prices in most developing countries in this study.

Also, it was found that the influences from the international grain prices on domestic grain prices were less in $R_{2}$ relative to those in $R_{1}$ in these countries such as Tunisia, Benin and Niger for rice and Chad, Nicaragua and Guatemala for maize. However, the influences for those countries in which wheat are staple food were found to be lager or equal in $R_{2}$ relative to those in $R_{1}$, such as Armenia, Georgia, Mauritania and Pakistan for wheat and Nicaragua and Cameroon for rice.

\section{Limitation of this Study}

For some cases, the influences of international prices during/after the hikes were larger than before; however, for other cases, the influences during/after the hikes were smaller than before. This may be due to that whether 
they took some effective policy interventions to control the prices or not in these countries. The more concrete and specific reasons as well as factors that affected the differences in price transmission in each country should be analyzed in the future studies.

\section{Acknowledgement}

The Authors wish to express their sincere appreciation for the comments from the anonymous reviewers and CSC Scholarship from People' Republic of China for their support for several years until the completion of this work.

\section{Author's Contributions}

Shuqin Yan: In charge of the whole process including research preparation and operation process, writing, modification and publication of this manuscript.

Kolawole Ogundari: Contributed to the process of choosing and modifying the model for methodology part of preparation and answering process for comments from reviewers.

Hiroshi Isoda: Gave first author comments when presentation at the seminars in preparing process.

Shoichi Ito: Contributed to the process of preparation, writing and modification of this manuscript.

\section{Ethics}

This article is original and contains unpublished material. The corresponding author confirms no ethical issues involved.

\section{References}

Ailliot, P. and V. Monbet, 2012. Markov-switching autoregressive models for wind time series. Environ. Modell. Software, 30: 92-101.

DOI: $10.1016 /$ j.envsoft.2011.10.011

Arezki, R., D. Lederman and H. Zhao, 2011. The relative volatility of commodity prices: A reappraisal. Am. J. Agr. Econ. DOI: 10.1093/ajae/aat050

Brummer, B., S.V. Cramon-Taubadel and S. Zorya, 2009. The impact of market and policy instability on price transmission between wheat and flour in Ukraine. Eur. Rev. Agric. Econom., 36: 203-230. DOI: $10.1093 / \mathrm{erae} / \mathrm{jbp} 021$

Cao, Z., S. Ito, H. Isoda and H. Saito, 2013. Grain price transmission from international markets to Chinese domestic markets. J. Fac. Agric. Kyushu Univ., 58: 499-507.

Dickey, D.A. and W.A. Fuller, 1979. Distribution of the estimators for autoregressive time series with a unit root. J. Am. Stat. Associat., 74: 427-431. DOI: $10.2307 / 2286348$
FAO, 2011. Food security and agriculture highlights of FAO: Armenia, food security information for decision making. Food and Agriculture Organization.

FAO, 2014a. GIEWS food price data and analysis tool. Food and Agriculture Organization.

FAO. 2014b. Food and agriculture policy decision analysis, Guatemala, Country fact sheet on food and agriculture policy trends. Food and Agriculture Organization.

Hamilton, J.D., 1996. This is what happened to the oil price-macroeconomy relationship. J. Monetary Econom., 38: 215-220. DOI: $10.1016 / \mathrm{S} 0304-3932(96) 01282-2$

Huchet-Bourdon, M., 2011. Agricultural commodity price volatility: An overview. OECD Publishing. DOI: $10.1787 / 18156797$

Ihle, R., S.V. Cramon-Taubadel and S. Zorya, 2009. Markov-switching estimation of spatial maize price transmission processes between Tanzania and Kenya. Am. J. Agric. Econom., 91: 1432-1439. DOI: $10.1111 /$ j.1467-8276.2009.01360.x

IMF, 2006-2014. International Financial Statistics (IFS) and world economic outlook database. International Monetary Fund.

Ito, S., 2014. World food statistical graphics.

Kim, C.J., 1994. Dynamic linear models with markovswitching. J. Econom., 60: 1-22. DOI: 10.1016/0304-4076(94)90036-1

Minot, N., 2010. Transmission of world food price changes to markets in Sub-Saharan Africa. Trade and Institutions Division, International Food Policy Research Institute.

Pindyck, P.S., 2004. Volatility and commodity price dynamics. J. Futures Markets, 24: 1029-1047. DOI: $10.1002 /$ fut.20120

Phillips, P.C.B. and P. Perron, 1988. Testing for a unit root in time series regression. Biometrika, 75: 335-346. DOI: 10.1093/biomet/75.2.335

Prakash, A., 2011. Safeguarding food security in volatile global markets. Food and Agriculture Organization. Rome, Italy.

Robles, M. and B. Cooke, 2009. Recent food prices movements: A time series analysis. International Food Policy Research Institute.

Robles, M., 2011. Price transmission from international agricultural commodity markets to domestic food prices: Case Studies in Asia and Latin America. IFPRI, Washington, DC.

Wooldridge, 2009. Introductory Econometrics. 5th Edn., pp: 704 .

WB, 2013. Country-classifications. World Bank.

Yarmohammad, M., H. Mostafaei and M. Safaei, 2012. Markov switching models for time series data with dramatic jumps. Sains Malaysiana, 41: 371-377.

Zivot, E. and D.W.K. Andrews, 1992. Further evidence on the great crash, the oil-price shock and the unit-root hypothesis. J. Bus. Econom. Stat., 10: 251-270. DOI: $10.1198 / 073500102753410372$ 